desde la academia

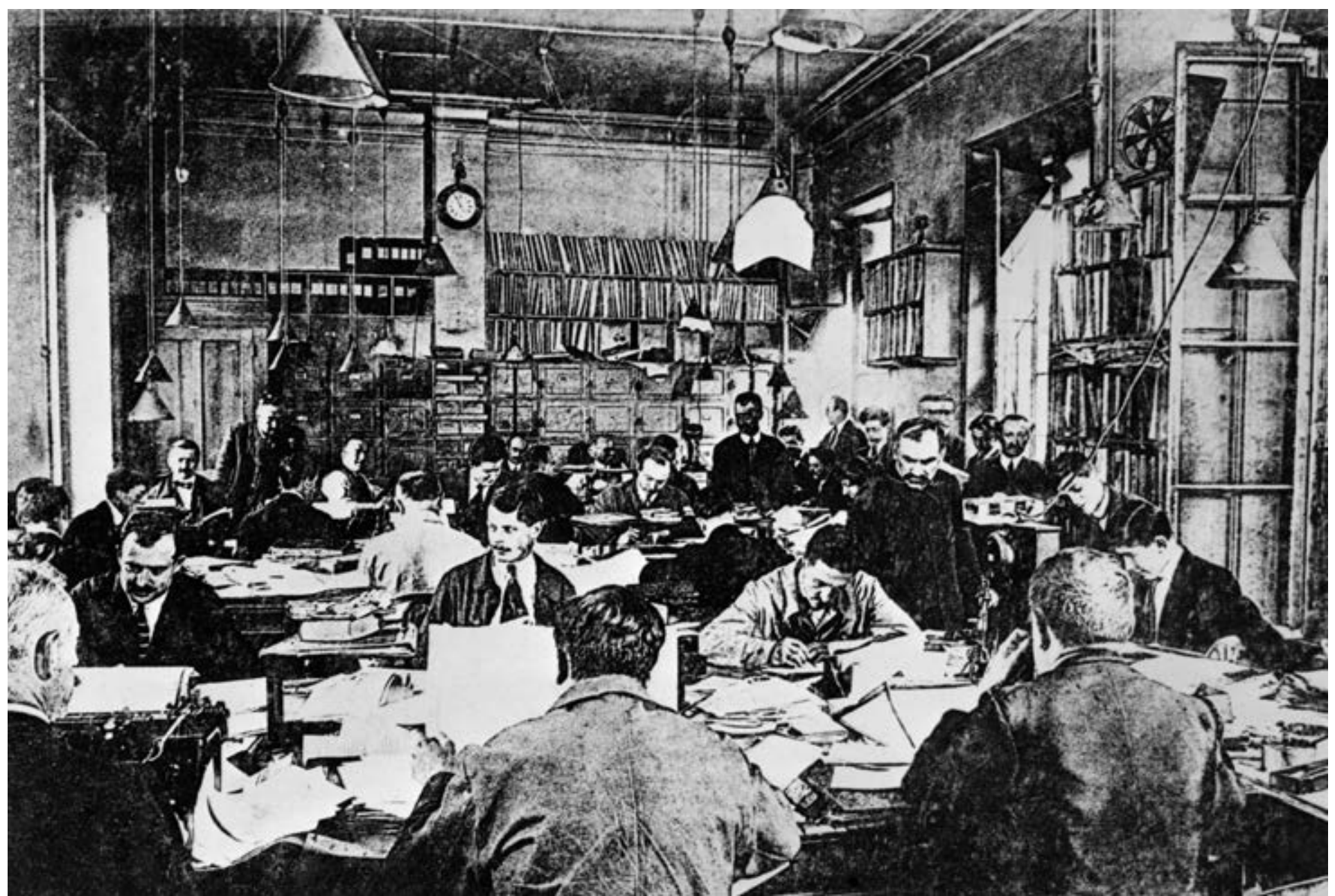

Foto: $\odot$ AFP Photo

\title{
Asedios de la prensa de barricada y la prensa satírica en el Chile del siglo XIX
}

Sieges of the barricade press and the satirical press in the 19th century in Chile

DOI: https://doi.org/10.22235/d.v0i27.1496

Carolina Carvajal y Claudio A. Véliz Rojas 
RESUMEN

El presente artículo tiene como propósito explorar la dimensión transgresora de la prensa de barricada y la prensa satírica del siglo XIX en Chile, en el contexto de formación de repúblicas. A través de la revisión de los periódicos de autores como Santiago Arcos, Eusebio Lillo, Francisco Bilbao y Juan Rafael Allende, el análisis propuesto busca postular ambos tipos de prensa como un arma fundamental de transformación e intervención en la sociedad decimonónica. El estudio de estos tipos de prensa sirve como acercamiento a un periodo fundacional, en el que se configuraron los rasgos políticos, sociales y económicos de los países americanos.

Palabras clave: prensa; siglo XIX; sociedad; barricada; sátira.

\section{Introducción}

Plantear una historia de la prensa es una forma de acercarnos a nuestro devenir como americanos insertos en el discurso de la modernidad e introducirnos en el panorama identitario de la nacionalidad. Conscientes del desafío que implica reconstruir la historia de la prensa en nuestro continente, con este artículo pretendemos realizar una contribución mediante el análisis de dos voces fundamentales para el caso chileno de la segunda mitad del siglo XIX: la prensa de barricada y de la prensa satírica. Consideramos que estas voces, que no han recibido suficiente atención por parte de los estudios académicos, permiten reflexionar en torno al fuerte campo de disputa que significó la prensa en el siglo XIX.

En este marco, proponemos como hipótesis que estas prensas funcionaron como asedios a los grupos empoderados y lograron, con textos e imágenes, desenmascarar a una clase política, un gobierno y otros actores de la época, como la Iglesia Católica. Ambas prensas surgieron en momentos específicos del devenir de la historia republicana chilena y se instauraron como auténticas armas de respuesta al poder hegemónico que catalizaron, a su vez, el estallido social ${ }^{1}$.

\section{ABSTRACT}

This article explores the transgressor dimension of the barrice press and the satirical press in the 19th century in Chile in the context of formation of Republics. The analysis pretends to establish that both types of newspapers were a fundamental weapon in the transformation and intervention in nineteenth-century society. This is reflected in the journals of authors as Santiago Arcos, Eusebio Lillo, Francisco Bilbao y Juan Rafael Allende. The study of these types of press serves as an approach to a foundational period, in which the political, social and economic features of the American countries were configured.

Keywords: press; 19th Century; society; barricade; satire.

El análisis se llevará a cabo mediante la revisión de versos y caricaturas aparecidos, respectivamente, en la prensa de barricada (El amigo del pueblo, de Eusebio Lillo, Francisco Bilbao y Santiago Arcos) y en la prensa satírica (El Padre Padilla, de Juan Rafael Allende). Pero antes de desembocar en nuestro punto de interés, valgan algunas reflexiones previas.

\section{La prensa latinoamericana en el XIX}

En su texto La prensa chilena del siglo XIX, Eduardo Santa Cruz (2010) señala que los procesos de independencia y creación de nuevas repúblicas latinoamericanas, como en el caso de México y Perú, fueron un antecedente en la eclosión periodística del continente:

Pareciera indudable que la lucha por la independencia y la inmediatamente siguiente por el control de las nuevas realidades y políticas crearon condiciones que antes no existían para que la prensa asumiera el rol de instrumento privilegiado por las facciones y grupos que se disputaban el nuevo orden (p.15).
Carolina Carvajal Pontificia Universidad Católica de Chile Santiago, Chile ctcarvaj@uc.cl

Claudio A. Véliz Rojas Universidad Central de Chile Santiago, Chile. cvelizro@gmail.com

Recepción: 01/10/2017 Aceptación: 25/11/2017
1:: La prensa de barricada y la prensa satírica anticiparon las guerras civiles de 1851 y 1891, respectivamente. 
Como órgano formador de opiniones y constructor de ciudadanía, la prensa, desde los albores de la independencia, respondió a la necesidad de formar una opinión pública que diera sustento a los discursos confrontados. La oposición entre monárquicos e independentistas no solo se dio como un enfrentamiento en el campo de batalla, sino también como la lucha por conquistar los medios que permitiesen convencer a unos públicos emergentes sobre la necesidad de un rey o un Estado. La necesidad de contar con una imprenta que permitiese la diversificación de una posición otra fue construida en gran parte, según Benedict Anderson (1993), desde la misma prensa americana. A ello podríamos atribuir la necesidad de acompasar los avances de la prensa junto a la educación de los pueblos; alianza que se ubica como sello de la democratización de los espacios a través del soporte periodístico.

Elías Palti (2003), en Los diarios y el sistema politico mexicano en tiempos de la República Restaurada 18671876, destaca la capacidad de la prensa para operar e intervenir políticamente "sirviendo de base para los diversos intentos de articulación [o desarticulación] de redes politicas" (p.177). Ante esta reflexión del historiador argentino, podemos decir que los periódicos decimonónicos eran capaces de generar cortes, abrir fisuras, coronar y destronar figuras del ámbito público. La prensa era en sí misma una forma de actuar políticamente. Esto lo advierte también Paula Alonso (2004) en Construcciones impresas. Panfletos, diarios $y$ revistas en la formación de los estados nacionales en América Latina, 1820-1920, al aludir al carácter político del medio:

La prensa irrumpió con fuerza en América Latina con los conflictos políticos e ideológicos que rodearon la Independencia y continuó siendo a lo largo del siglo, y aún entrado el siguiente, una de las principales formas de hacer política (p.18).
Podemos agregar que, por ese mismo hecho de generar política, la prensa contribuyó a construir las imágenes de las naciones emergentes, al tiempo que iba esbozando un campo de identidad para el sujeto nacional que se identificaría con una $u$ otra facción política a través de las opiniones vertidas en ella.

Por otro lado, como lo ha indicado Julio Ramos (2003) en Desencuentros de la modernidad en América Latina, la prensa durante el siglo XIX se instituyó como un espacio para la diversificación del campo intelectual. Diversos fundadores de nación utilizaron los espacios de la prensa no solo para construir una opinión pública, sino para cimentar sus lugares en el campo cultural de sus respectivas épocas. Estableciendo posiciones que se harían extensivas a partidos políticos sólidos a largo siglo XIX, Camilo Henríquez, Fernández Lizardi, Domingo F. Sarmiento, Eugenio María de Hostos, entre otros, delinearon el rol de la intelectualidad americana en oposición a otros agentes. Ya a partir del último cuarto del siglo XIX, la prensa se consagrará como el lugar de las letras. Ramos (2003) acota que en ese momento "cambia el lugar del periodismo en la sociedad, es el interior de una transformación más amplia del ámbito de la comunicación social" (p. 127). Esto lo ejemplificaremos para el caso chileno en el apartado que sigue.

\section{La prensa chilena en el siglo XIX}

Las características de la prensa chilena decimonónica se diagraman sobre las particularidades del período mismo, a saber: la lucha por la independencia, la formación de estados nacionales, la entrada del liberalismo y las consiguientes luchas ideológicas o los conflictos limitrofes, por mencionar algunas. Su historia se homologa, en cierta manera, al devenir de la prensa en América Latina. La diferencia respecto a las otras naciones puede hallarse en el grado de impacto en los pueblos así como el tardío desarrollo de la labor periodística en Chile. 
Como indica Bernardo Subercaseaux (2010), en su obra Historia del libro en Chile, la llegada de la imprenta recién hacia la primera parte de la independencia de 1811 contribuyó al retraso de una labor periodística que en otros países -como los virreinatos del Perú y México- se había iniciado ya en el siglo XVIII. ${ }^{2}$ Esto habla de un mercado cultural inexistente, que debió crearse con agilidad para respaldar argumentativamente el derecho a soberanía de los chilenos. Desde esta precariedad, la falta de públicos lectores y la carencia de medios para la circulación de los periódicos, era difícil imaginar que treinta años después, con las iniciativas de la generación de 1842 , se consolidaría una voz procultura en intelectuales como José Victorino Lastarria y su grupo. Como elite económica, cultural y social, este colectivo determinó una forma de poner en circulación las ideas y también los periódicos, en el sentido de su materialidad, con formatos que fueron variando.

El periódico El Progreso, de 1842, incluyó por primera vez una sección de gran valor durante el siglo XIX: el folletín. ${ }^{4}$ Hacia 1885 esa sección estaría presente con fuerza en periódicos como La Época que, en términos de Brunner y Catalán (1985), “encarnó ese espíritu renovador en la formación literaria del público lector" (p.105). Estamos así frente a una serie de páginas más interesadas en informar las últimas novedades culturales de Europa - por ejemplo, en el ámbito literario-que en seguir haciendo política. Así, al campo cultural chileno ingresan con gran éxito “[los franceses] -Taine, Daudet, Zola, Maupassant, Mallarmé, Goncout-, los españoles -Pérez Galdós, Palacio Valdés, Menéndez y Pelayo- y también los rusos, que comienzan a darse a conocer-Dostoyewski, Puskin, Tolstoi” (Brunner y Catalán, 1985, p.106). El periódico La Época no estuvo solo, sino que fue imitado por otros medios de prensa que introdujeron figuras como Gorki, Ibsen y Nietzche.
Estas lecturas, que se incorporaban al espacio cultural chileno, revisten una importancia quizá difícil de mesurar, si pensamos que varios de esos autores fueron grandes enjuiciadores de su tiempo y, en general, tenían una visión negativa de la modernización europea. Con ellos no ingresaron solo nuevas lecturas: ingresaron nuevas corrientes de pensamiento, nuevas sensibilidades, nuevos espíritus críticos y comprometidos con el quehacer social. Por ejemplo, la entrada al espacio cultural de Nietzsche, y su promulgación de la "muerte de Dios", tuvo vastas influencias en el sentir anticlerical y las campañas laicistas de la época, no solo en Chile, sino en el resto de los países latinoamericanos. Nicolás Casullo (1999), en La modernidad como autorreflexión, señala que esa muerte de Dios se gestó en un principio "como crítica a los dogmas de la Iglesia, como crítica a la hipocresía de las morales dominantes, como crítica a lo religioso autoritario, como crítica a la superstición, como crítica al mito" (p.12). Nos atrevemos a señalar que todo lo listado por Casullo es parte del discurso antirreligioso que plasma la prensa satírica en Chile, en especial, la de Juan Rafael Allende y su ardua campaña anticlerical.

Durante este período sobresalen también la crítica literaria ya propiamente establecida, el desarrollo de nuevos públicos, como las lectoras y las clases populares, así como la incipiente escisión de los escritores y la prensa. Poetas de profesión que se separarán de la prensa, críticos literarios que menospreciarán a los escritores que viven de los folletines, lectoras que fundarán sus propios espacios y saldrán en defensa de su identidad mujer, así como una lira popular que no acabará de fluir son elementos de este complejo mercado cultural ya en pleno funcionamiento hacia fines del siglo XIX en Chile. Estos y otros vínculos muestran una vez más a la prensa como una plataforma cultural subrogante a la inexistencia de un mercado que permitiese la circulación este tipo de escritos. Soporte de literatura, historia, ciencias sociales y ciencias exactas: la prensa en sus diversos formatos sirvió a la educación de otros públicos.
2:: De acuerdo a

Subercaseaux (2010), en México se instaló la primera imprenta en 1540 y la primera circulación de periódicos y gacetas fue en 1722. En Perú -el mercado cultural más cercano al chileno- la instalación de la primera imprenta data de 1581 y los primeros periódicos y gacetas circularon en 1700. En Chile, tanto la instalación de la imprenta como la puesta en circulación del primer periódico datan de 1811 .

3:: Cuando hablamos de determinación tenemos en cuenta que esa joven generación de 1842 se convirtió, a partir de 1860, en gobierno. Los intelectuales que fueron desplazados del gobierno por el ala conservadora, con la ruptura del gobierno de Manuel Montt, adquiririan una gran solidez que les permitiría retornar al país luego de sus exilios para aplicar modelos apropiados o reproducidos del extranjero. Desde 1876 a 1891, cada uno de los presidentes de Chile formó parte del cenáculo de 1842.

4:: En esta sección del periódico La Voz de Chile, en 1862, se publicó por primera vez la novela chilena fundacional Martín Rivas, de Alberto Blest Gana. 
5:: Fue el caso de Francisco Bilbao y El Amigo del Pueblo (1850) que se detalla a continuación.

6:: Bilbao (1823-1865) "fue el ícono de aquella generación, símbolo de radicalismo liberal que combatió a los gobiernos autoritarios en nombre

de una democracia plena, al mismo tiempo que llamaba a la unidad de los pueblos latinoamericanos para impugnar la amenaza imperialista. [...] Bilbao dedicó su vida a la causa de la democracia, pasando gran parte de ella en el exilio y sufriendo constantes persecuciones"

("Francisco Bilbao", s. f.).

7:: Lillo (1826-1910) formó parte de los jóvenes

liberales chilenos de mediados del siglo XIX que confluyeron en la Sociedad de la Igualdad.

En paralelo, incursionó en la literatura y participó en el Movimiento Literario de 1842; publicó sus obras en periódicos de Santiago de Chile y Valparaiso. En 1847, por encargo del gobierno chileno, compuso la letra del nuevo Himno Nacional

("Eusebio Lillo", s. f.).
Por otro lado, junto con el desarrollo de la prensa, se fueron instaurando también reglas y normativas que permiten comprender el poder de estos medios escritos y su potencial peligrosidad para los gobiernos de turno. En este tenor, en 1846 se aprobó en Chile un decreto ley que indicaba la subvención del Estado a determinados periódicos, como apoyo al desarrollo político, social y cultural del país. Comprendiendo que esta ayuda estaba basada en la preferencia del gobierno, es importante aclarar que, si bien la prensa se estableció como un espacio de debate, este debía ir acompañado por un capital que pudiera sustentar el pago de un tiraje, de los tipógrafos y de la propia divulgación de los periódicos. Es por ello que algunas voces de la prensa tuvieron lugares menos visibles. Es el caso de una prensa de representación popular que no tendrá su momento de eclosión hasta el último cuarto del siglo XIX, aun cuando hubo movimientos elitistas para mediados de siglo que, suplantando la voz del pueblo, ${ }^{5}$ se embanderaron con ideas extranjeras y llevaron a la revuelta social. Esto se debió, sobre todo, a que el fenómeno del movimiento obrero, al menos en Chile, no pudo apreciarse en plenitud sino hasta el último cuarto de siglo.

Las relaciones internacionales de Chile también fueron determinantes en la conformación de la prensa decimonónica. En las últimas decenas del siglo XIX, el país creció imperialmente gracias a la Guerra del Pacífico (1879-1884). Este conflicto bélico, que confrontó a Chile por segunda vez en el siglo ante la alianza Perú-Bolivia, dejó un importante saldo para la posteridad: un auspicioso crecimiento económico para las quebradas finanzas chilenas, la pérdida territorial de Perú y la mediterraneidad forzada de Bolivia. Este aumento de capitales permitió un prolongado período de bonanza económica que operó como factor relevante en el crecimiento de la circulación de la prensa chilena en el plano internacional.

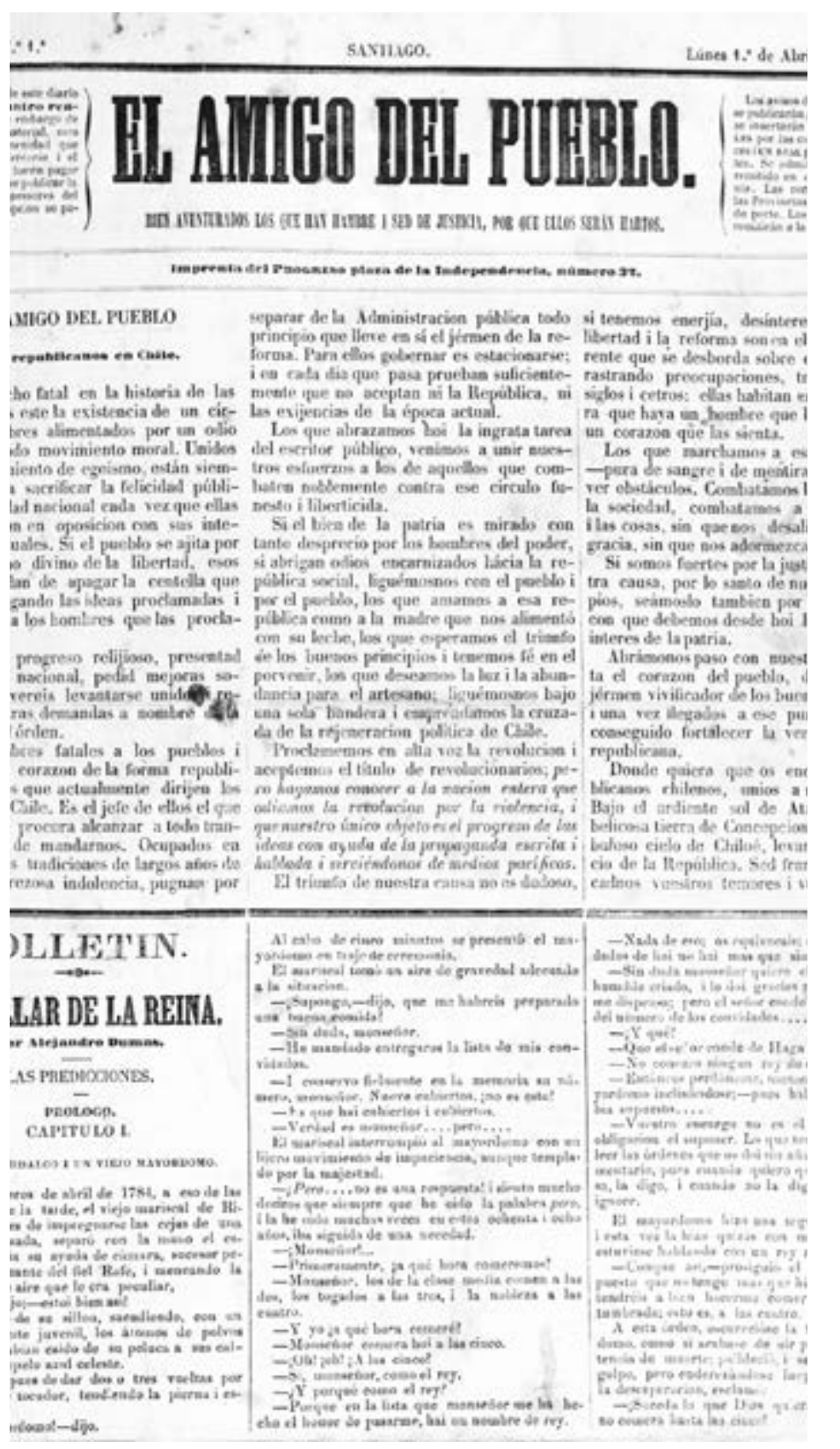

Fuente: "El Amigo del Pueblo" (1850) 
Hechas estas consideraciones, pasaremos a un breve análisis de la desaforada crítica de las barricadas hechas periódicos a mediados del siglo XIX.

\section{Las poesías en el Amigo del Pueblo:} rupturas y desbordes

Con cincuenta y tres números publicados, a tres columnas, cinco filas en la portada y una serie de textos sin autor, El Amigo del Pueblo se comenzó a publicar, de forma provocativa, en plena Semana Santa: el $1^{\circ}$ de abril de 1850. Pensado para un público de pocos medios y redactado por los jóvenes Francisco Bilbao ${ }^{6}$, Eusebio Lillo ${ }^{7}$ y Santiago Arcos, ${ }^{8}$ este periódico -que parafraseaba al famoso pasquín de Jean Paul Marat- incitó, desde sus primeros números, al debate por los valores tradicionales de la época. Este órgano mediático de la Sociedad de la Igualdad $^{9}$ ciertamente representó un ataque directo al gobierno conservador.

Ahora bien, el investigador Carlos Ossandón (1998), en su texto El crepúsculo de los sabios y la irrupción de los publicistas: prensa y espacio público en Chile, sugiere que este periódico podría ser clasificado como una parte fundante de la 'prensa de ariete'. Profundamente ideológico y en abierto ataque al orden establecido, El Amigo del Pueblo provocó directamente a las instituciones chilenas. Lo hizo por medio de textos y sugerencias a favor de una noción de 'pueblo oprimido' que demostraban con claridad su rechazo tanto al gobierno como, por qué no decirlo, a la misma oposición. ¿Qué estrategias utilizaba para ello? Sus líneas editoriales, los avisos comerciales, las cartas al periódico, los sainetes creados por los redactores, entre otros artefactos textuales que sirvieron como proyectiles disparados contra el gobierno y su proyecto de nación.

Para este trabajo ahondaremos en un ámbito poco revisado: el accionar de las poesías como armas de ataque contra los opositores. La poesía, hacia mediados del siglo
XIX chileno, conserva una apreciación aceptada para las discusiones de la época, así como, muchas veces, para la crítica posterior: un sentimentalismo exacerbado, un personalismo omnipresente, una retórica llena de lugares comunes y un ensalzamiento de la nación desde una estilística recargada y aburrida ${ }^{10}$. Sin embargo, ¿Qué ocurre cuando la poesía deja ese rol melancólico o personalista, y toma un ribete más social y polémico?

Aun cuando para los críticos literarios el rol político de la poesía decimonónica no se presenta como una novedad para el campo, resulta destacable que, en los últimos años, se haya realizado toda una revisión de los caminos (¿alternativos?) que tomó esta poesía chilena en otros espacios. Evidencia de ello es que los estudios respecto a la lira popular se hayan perfilado como un nuevo y rico campo de estudio para comprender una proyección poética que no solo varía en sus temáticas más sociales y comprometidas, sino que también altera la comprensión de la crítica histórico-literaria frente a los espacios de circulación de estas décimas.

De ahí que entendamos necesaria una revisión de las poesías de El Amigo del Pueblo como una vía que rompe con el esquema de la lírica sentimental y personalista, tan afincada en el imaginario de la crítica cultural, y resignifica el periódico de trinchera como un espacio que contiene textos líricos planteados en clave de profundos problemas para la construcción del proyecto nacional burgués de mediados de siglo. Cercanos al ejercicio de la lira popular chilena, los versos publicados en El Amigo del Pueblo se oponen -desde su lenguaje, contexto y temática- a un enemigo con múltiples rostros: Manuel Montt (presidente de Chile entre 1851 y 1861), el conservadurismo, la Iglesia Católica, entre otros. Desde su primer número, y con la pluma del poeta Eusebio Lillo a su favor, el periódico sugiere derribar al candidato Montt para lograr una regeneración social. Así queda ejemplificado en los versos de La musa en día de Pascua:
8:: "De ideas románticas y asiduo asistente a los salones de la intelectualidad liberal y de los clubes políticos de inspiración socialista, el menor de los Arcos Arlegui (1822-1874) se transformó en un trotamundos de espíritu libre y aventurero [...]. De vuelta en Chile emprendió la creación de la Sociedad de la Igualdad en marzo de 1850"

("Santiago Arcos", s. f.).

9:: Este grupo planteaba "la necesidad de una transformación revolucionaria de la sociedad que daría inicio a una nación de hombres libres e iguales. Inspirada en los ideales de las revoluciones de 1848, fue la primera vez que los intelectuales radicales establecieron alianzas con sectores populares" ("Sociedad de la Igualdad", s. f.).

10:: Al respecto, Joaquín Blest Gana (1848) indicó: "los defectos artísticos de la poesia chilena son la superficialidad y el egoísmo, la ausencia de un espíritu general extensivo a toda ella y al oprobio a falta de nacionalidad" ( $p$. 351). Asimismo, Alberto Blest Gana (1861), en un discurso de la Universidad de Chile, dijo: "La novela tiene un mayor público que la poesía, la novela debe ser sobre la poesía". 
¿Quieres vestirte a la usanza/ del círculo Mon?/ Toma frac verde esperanza/ i empuña bastón; / I con ceño de inclemencia/ que pueda asustar/ Los aires de presidente/ procura tomar. / Cuida de afectar desprecio/ por lo juvenil, / I llamar al pueblo, necio,/ cobarde i servil (Lillo, 1850, p. 3).

Contra Montt y su partido, contra los opresores del pueblo -en una amplitud conceptual que comprende al artesano, al obrero, al guardia civil, entre otros subgrupos de la clase popular-, este fragmento incita al lector a que mire, desde el imaginario que el periódico soporta, el futuro que podría depararle bajo el mando de Montt. Este presagio del porvenir (no por nada Eusebio Lillo fue visto durante el siglo XIX como el profeta del pueblo) sería una línea constante en las veinte poesías que comprenden los cincuenta y tres números del periódico. Bajo el mismo temple, el número 18 del periódico publica, en su sección de Correspondencia, el poema $E l$ sueño del verdugo:

Maese Manuel, Verdugo de mi aldea, / De ruin aspecto i de feroz mirar, / Para llevar a cabo su tarea/ Calma solía al vino demandar. / La furia del licor pudo en un día, / Hacer brotar en su alma la ambición, / Y embriagado el verdugo repetía, / Yo seré rey pues tengo vocación ("El sueño del verdugo", 1850, p. 4).

A través de recursos metafóricos ("el sueño", por ejemplo), estos poemas suelen utilizar el último verso de sus estrofas para reiterar el mensaje a su público lector, en este caso: “yo seré rey pues tengo vocación”. La reiteración como estrategia de reforzamiento, para un lector que debe ser persuadido de que 'la patria que está en peligro', se acentúa con el recuerdo de la monarquía para una nación que se siente orgullosa de su tradición republicana. Sin olvidar su propósito de condenar públicamente a Montt como figura de anatema para la sociedad santiaguina: el nombre del futuro presidente aparece vinculado a una serie de estereotipos negativos que estriban tanto en su historia personal como hasta en su propio cuerpo. Así lo expresa el poema El Petorquino, en el número 24 de la publicación:

Y de la Petorca trajo/ Como él, negra hipocresía, / Así es que su gran trabajo/ Alcanzó una inspectoría, / El de Petorca espantajo ("El Petorquino", 1850, p. 3).

Con un desprecio continuo hacia Montt, estos versos mezclan la historia conocida por el público sobre el origen provinciano del candidato (viene de un pueblo llamado Petorca) y su trayectoria profesional, que no lo separaría de su condición de "espantajo". Esta diferenciación y la insistencia en su estar fuera de lugar, respecto al territorio en el que circula el poder, se remarcan en el poema:

Y allá en Petorca creció; / Y de Petorca aquí vino, / Y al instituto se entró, / Pero aunque aquí se educó, / Siempre será petorquino ("El Petorquino", 1850, p. 3).

De esta forma, la educación no puede salvar el pecado de origen del aludido. El petorquino es "de allá" y en el desplazamiento logró arribar a un "aquí" del poder, del centro, pero, aunque educado, el pecado de origen subsiste: haga lo que haga el personaje, siempre será un pueblerino.

Por otro lado, y ya en un plano que pasa de lo axiológico a lo material, la "negra hipocresía" del petorquino no solo alude a su capacidad para ascender socialmente a través de las mentiras, sino también a un cuerpo que es "oscuro": "Que en Petorca parecía/higo seco en una higuera" ("El Petorquino", 1850, p. 3). La cualidad oscura del personaje, frente a la idea de blancura defendida por el imaginario popular para una figura de autoridad y bondad, responde a una marca de raza que está distin- 
guiendo, en un siglo de máximo cientificismo, el "fuera de lugar" en que se ubica al futuro presidente de Chile.

Ahora bien, ¿son efectivamente transgresoras estas poesías para la creación de estos nuevos públicos lectores? Si bien el impacto de este periódico se traduce en su cierre forzado, provocado por la autoridad conservadora de la época -especialmente la curia católica-, estas poesías ocupan un puesto de avanzada en la polémica creada por el soporte del periódico. A partir del número 8, todos los poemas comienzan a ser expuestos en la sección de Correspondencia, con lo que se asume una estrategia que podría explicar los gustos de un público que consume este periódico y que mantiene un diálogo con él. Esta sección también envía un mensaje a ese público y abre el diálogo a temas concernientes al texto, pero releva a los redactores y al periódico en sí de la responsabilidad por lo que otros puedan enviar. Veamos el siguiente ejemplo:

Nuestras columnas están abiertas a estos desahogos generosos del hombre del pueblo, y nos hacemos un honor al publicar estos escritos, que si no tienen la corrección y la pureza de lenguaje de los del hombre de esmerada educación, al menos revelan un corazón noble y patriota y sentimientos republicanos [cursivas añadidas] (“Correspondencia”, 1850, p. 3).

Este mecanismo de catarsis para "el hombre del pueblo" se establece con un intento de mediación para el público, pero sin perder el lugar letrado que se autoasegura la redacción del periódico. Estos hombres no tienen el poder de la palabra -el poder de la gramática, el buen decir/escribir (según Ramos, 2003)-, pero (al menos) representan la pureza del cuerpo republicano. Desmarcándose de la escuela de la elocuencia propuesta por Andrés Bello (Ramos, 2003), los textos líricos en este periódico se presentan barbarizados aunque nobles en su esencia (¿la poesía del buen salvaje?). De ahí que resulte interesante preguntarnos: ¿qué tan lejos fue la autorización de este salvajismo en la República de las letras? La trinchera letrada, al parecer, tuvo un amplio campo para derribar al enemigo y para reconfortar al amigo salvaje.

La Iglesia Católica también tuvo un rol protagónico en los versos de El amigo del Pueblo. Desde un lenguaje que abogaba por la imitación del Jesucristo para los pobres, hasta el subtítulo que acompañaba al periódico en sus ediciones - "Bienaventurados los que han de sed y justicia, porque ellos serán hartos”-, el enfrentamiento al orden eclesiástico en sus propios significantes tomó un nivel inusitado para la época y colocó al periódico en serios conflictos con sus aliados (Collier, 2005). El número 23 del periódico comenzó a publicar el texto Las palabras de un creyente, del excomulgado abate Felicité Lamennais, obra que habria sido traducida por Francisco Bilbao. Ante esta polémica decisión editorial, La Revista Católica (18431894) respondió declarando el carácter anticatólico, no solo de la obra de Lamennais, sino del mismo El amigo del Pueblo. En este complejo escenario, el coronel Correa da Costa -autor proclamado como amigo de la publicación igualitarista- contestó a La Revista Católica con una carta de apoyo al periódico de Lillo, Arcos y Bilbao. Da Costa cerraba su argumentación con un breve poema para reforzar el contenido de su mensaje:

No pertenece a los padres/ Los negocios seculares; / Los padres han sacudido/ Los tronos i los altares. / Jesu-Cristo nunca fué/ De «Revistas» redactor: / Servir a Dios i al mundo, / No es justo, no señor, / Para el servicio divino, / Erijido fué el altar; / En el poder temporal, / La iglesia no debe entrar (Correa da Costa,1850, p. 3).

Por medio de esta estrategia retórica, el periódico impone la partición clásica de los dominios del hombre y la Iglesia, y mantiene el control del discurso periodístico en un plano exclusivamente laico. En un juego de respuestas y contrarrespuestas, el texto alienta la separación del poder espiritual fuera del discurso 
mediático desarrollando un argumento que permita desplazar la reacción letrada católica, como un trabajo ajeno al símbolo cristiano: 'si quieres imitar a Jesuscristo, Jesuscristo no fue redactor de Revistas'. El ámbito del negocio, de esta manera, queda en el conservadurismo laico y en la oposición, pues los negocios seculares no deben ser intervenidos por la Iglesia. De esta manera, la institución católica, bajo la perspectiva del autor y del soporte, debe orientar sus preocupaciones hacia aspectos más trascendentales que las parcelas materiales (política y sociedad) encontradas en disputa.

Sobre lo dicho, y como otro artilugio de esta prensa de ariete decimonónica, es que apreciamos en el número 31 un enganche publicitario con el lector original. Al ofrecer la posibilidad a su público de completar el poema, los redactores invitan a su público a ser parte de sus ataques contra el poder eclesiástico. Se proponen las siguientes consonantes para una décima:

A un Fariseo

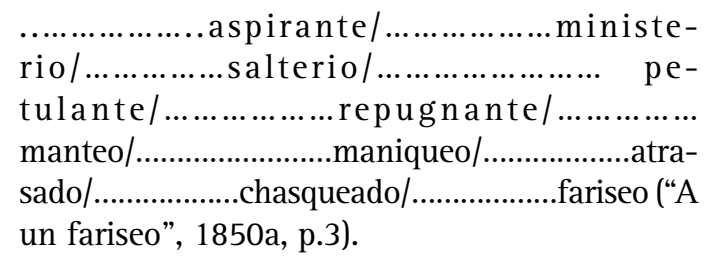

Tras dicha tentativa, el periódico ofrece la respuesta en su siguiente número:

\section{A un Fariseo}

En vez de ser aspirante/ i pretender ministerio/ Vete a leer en el salterio/ I no seas petulante/ Tu figura repugnante/ Oculta bajo el manteo/ Que aquel que es un maniqueo, / En ideas atrasado. / Ha de ser siempre chasqueado, / Hipócrita fariseo (“A un fariseo", 1850b, p. 3).
De ambición enaltecida, petulante en su modo de actuar y con una cualidad negativa que impacta más allá de lo puramente valórico -repugnante bajo el "manteo"-, el personaje presentado en esta décima tiene una sola virtud, en desmedro de múltiples descalificaciones. Totalmente negado en su calidad amateur y ambicioso hasta la hipocresía, que le condena bajo la nomenclatura de "fariseo", el ataque del periódico se hace evidente no solo en su contexto de emergencia/soporte, sino también como una invitación extendida al público para criticar el estereotipo de los eclesiásticos.

De esta forma, las estrategias que habrían sido empleadas con acierto y alevosía para mediados del siglo XIX, en los confines del mismo período se perfeccionarían como armas certeras de transformación e intervención en la sociedad decimonónica chilena.

La prensa satírica en Chile:

el caso de Juan Rafael Allende

Mucho antes de que se dispusiera de imprenta, comenzaron a circular por las calles de Santiago de Chile pasquines de contenido político-satírico. Ricardo Donoso (1950), autor de La sátira politica en Chile, ubica su nacimiento en 1811. Ese estudio, que aborda la sátira política desde los albores del siglo XIX hasta mediados del siglo XX, responde a la inquietud del autor por un campo de estudios que él mismo señala como insuficientemente abordado y sobre el cual quedan todavía muchos vacíos por llenar e inquietudes por responder. ¿Cuáles serían los inicios de la prensa satírica en Chile? Si nos guiamos por el estudio de Donoso, tendríamos que decir que se remontan a 1858 , cuando aparece el periódico El correo literario ${ }^{11}$.

Las creaciones literarias y artísticas (grabados y litografías) de corte satírico se intensificaron en la América Latina finisecular, cuando los intelectuales buscaron articular diversos sistemas simbólicos para hacerse cargo de su contexto: intensos debates entre ciencia 
y religión, procesos de secularización de Estados y construcción de nuevas repúblicas. A este respecto podríamos mencionar el caso de la prensa satírica en Venezuela y el rol preponderante de la caricatura como herramienta para ejercer presión social. También en el último cuarto del siglo XIX podemos mencionar las revistas venezolanas El Zancudo (1876), Fígaro (1878), El Charivari (1878), entre otras. Manuel Pérez Vila (1979), en su completo estudio La caricatura politica en el siglo XIX, señala que las composiciones e imágenes satíricas que aparecen en la primera década del siglo XIX en Venezuela, y que se intensifican después de la segunda mitad del siglo, operaron en ese país develando los aspectos más ridículos y negativos las clases políticas (p.6) y funcionando como armas psicológicas, satírico-moralizantes y político-sociales que intervenían en las luchas partidistas y exhibían las debilidades del adversario de turno (p.7).

Es probable que el prolífico desarrollo de la prensa satírica en Chile se debiese a lo que explica Donoso (1950): "El humor de los chilenos encontró en aquellos cauces el conducto para exponer opiniones que la parsimonia de la vida social y política consideraba intolerables" (p.7). A esto debemos sumar, sin duda, la influencia de la actividad satírica en la Europa decimonónica con revistas como Punch, en Inglaterra, y Le Charivari ${ }^{12}$ y La Caricature, en Francia. Ahora bien, para profundizar en el análisis nos vamos a centrar en la producción de Juan Rafael Allende (1848-1909), específicamente en un par de glosas y caricaturas publicadas en El Padre Padilla (1884-1888) ${ }^{13}$. Este autor concibe su creación dentro de un marco que excede lo periodístico y lo literario, y se posiciona en diferentes frentes retóricos que le permiten responder a las vicisitudes de su tiempo y apelar tanto a públicos letrados como no letrados.

A través de su prensa, Allende participó de manera decidida en las luchas políticas que marcaron la mo- dernización y secularización de la sociedad chilena durante el último tercio del siglo XIX. Sufrió muchas veces los efectos de la persecución y la violencia políticas, y hasta fue condenado a muerte en 1891 (pena de la que se liberó en el último momento). Armado de su propio taller de impresión y litografía, Allende fundó, dirigió, editó y redactó alrededor de 15 periódicos a lo largo de su carrera. Estos destacaban por su vistosa diagramación, sus combativas posiciones políticas -abiertamente anticlericales-y, sobre todo, por el estilo satírico y burlón de su pluma, como se deja ver en los mismos nombres con que bautizó sus periódicos: El padre Cobos (1879), El Ferrocarrilito (1880), El Padre Padilla (1884), Don Cristóbal (1890), Pedro Urdemales (1890), Poncio Pilatos (1893), El Josefino (1894), El Arzobispo (1895), Don Ma-ri-ano (1895), El Jeneral Pililo (1896), El Sinvergüenza (1897), La Beata (1897), El Tinterillo (1901) y El Sacristán (1902) ${ }^{14}$. Los periódicos de Allende gozaron de enorme popularidad en las capas medias y bajas de la sociedad:

Fue el autor predilecto de la población popular urbana de Santiago. Su literatura era un elemento cotidiano para muchos de sus habitantes. Sus periódicos empapelaban las habitaciones del pueblo, los restaurantes, o las fondas en Fiestas Patrias, y se vendían a viva voz en el sector del Mercado Central y la Estación Mapocho (Villalobos, 2015, p.58).

No resulta exagerado decir que Allende fue uno de los escritores chilenos que más controversia provocó entre sus contemporáneos, sobre todo entre quienes conformaban los grupos hegemónicos de la sociedad: la burguesía conservadora, la clase política y la Iglesia Católica. Allende apuntó sus dardos a estos colectivos, a través de un prolífico $\mathrm{y}$, por momentos, frenético trabajo de prensa que pretendía develar sus vicios y su hipocresía. Como ejemplo tenemos la glosa y el grabado El miedo lo hace obrar, publicados en El Padre Padilla, en el número 580, el 5 de julio de 1888:
12:: A propósito de la influencia de la prensa satírica europea, ya se mencionó la existencia de la revista venezolana $E I$ Charivari en 1878. Pues, en Chile, también apareció un periódico satírico titulado El Charivari, en 1865, cuyo propósito era burlarse del accionar del político Benjamín Vicuña Mackenna a propósito de los conflictos entre Chile y España.

13:: El Padre Padilla fue un periódico que durante sus cuatro años de publicación puso especial énfasis en los problemas de la sociedad chilena de la época, las desigualdades económicas los abusos del poder y el dinero. Cabe señalar que la Iglesia Católica, harta de los contenidos anticlericales, excomulgó este periódico en 1886

14:: Debemos mencionar la dificultad de hacer un conteo exacto de las publicaciones de Allende, debido a que solía cambiarles de nombre para burlar las persecuciones provenientes sobre todo del ámbito religioso. 
Imagen 1: El miedo lo hace obrar (caricatura). Fuente: Allende (1888)



El miedo es cosa viva, / lo dice así un refrán, / i dice Balmaceda/ que el miedo lo hace obrar. / No pongo en duda lo dicho/ de aquella Majestad, / i puesto que él lo dice/ lo cierto nos dirá / La democracia alzoze/ la loza sepulcral, / quitándose de encima, / clamando: ¡libertad! (Allende, 1888, n. ${ }^{\circ}$ 580).

Al más puro estilo de los emblemas del Siglo de Oro, Juan Rafael Allende solía publicar en sus periódicos estructuras tripartitas compuestas de una imagen, un mote y una glosa de contenido satírico y político. Como acota Pérez Vila (1979), suele suceder que en este tipo de caricatura la deformación o exageración de los rasgos físicos no sea lo más importante, pues lo que cuenta es que el personaje aludido sea identificado claramente "a fin de que la crítica pueda concentrarse en lo que ellos hacen y dicen, o dejan de hacer o decir" (p. 5).

En el caso de la litografía citada, la sátira de Allende no se dirige a lo físico, sino a lo moral. Lo que pretende exhibir es la flaqueza del presidente José Manuel Balmaceda, gobernante entre 1886 y 1891. La situación queda expuesta bajo el código carnavalesco del fisiologismo grotesco: el presidente está defecando. Domina el principio de lo bajo, donde lo bajo, tal como señala Bajtín (1987) en La cultura popular en la Edad Media y el Renacimiento, tiene un sentido topográfico: el vientre, el trasero y los órganos genitales (p. 25). El mandatario aparece dominado por las necesidades primarias, así se lo ridiculiza y desacredita. La ingeniosidad de Allende está dada por el juego de palabras; por la polisemia del verbo "obrar": Balmaceda actúa por miedo, el miedo tutela sus decisiones y acciones. Balmaceda defeca de miedo.

La siguiente pieza se titula Entre polleras y aparece también publicada en El Padre Padilla, en el número 447, un 2 de agosto de 1887. Se trata de unos versos satíricos que denuncian los retrocesos en materia de laicidad del Estado que tuvieron lugar durante el mandato de José Manuel Balmaceda. La caricatura que acompaña a estos versos retrata al mandatario como un bebé en el regazo de una beata, pero su rostro adulto es claramente reconocible. El texto reza:

El nene José Manuel/ es el chiche de las beatas, / y los jotes garrapatas / que hacen extremos con él /uno le muestra un juguete/ que representa a la vista, / un lindo seminarista/ con sotana y bonetes. (Allende, 1887, n. ${ }^{\circ} 447$ ) 


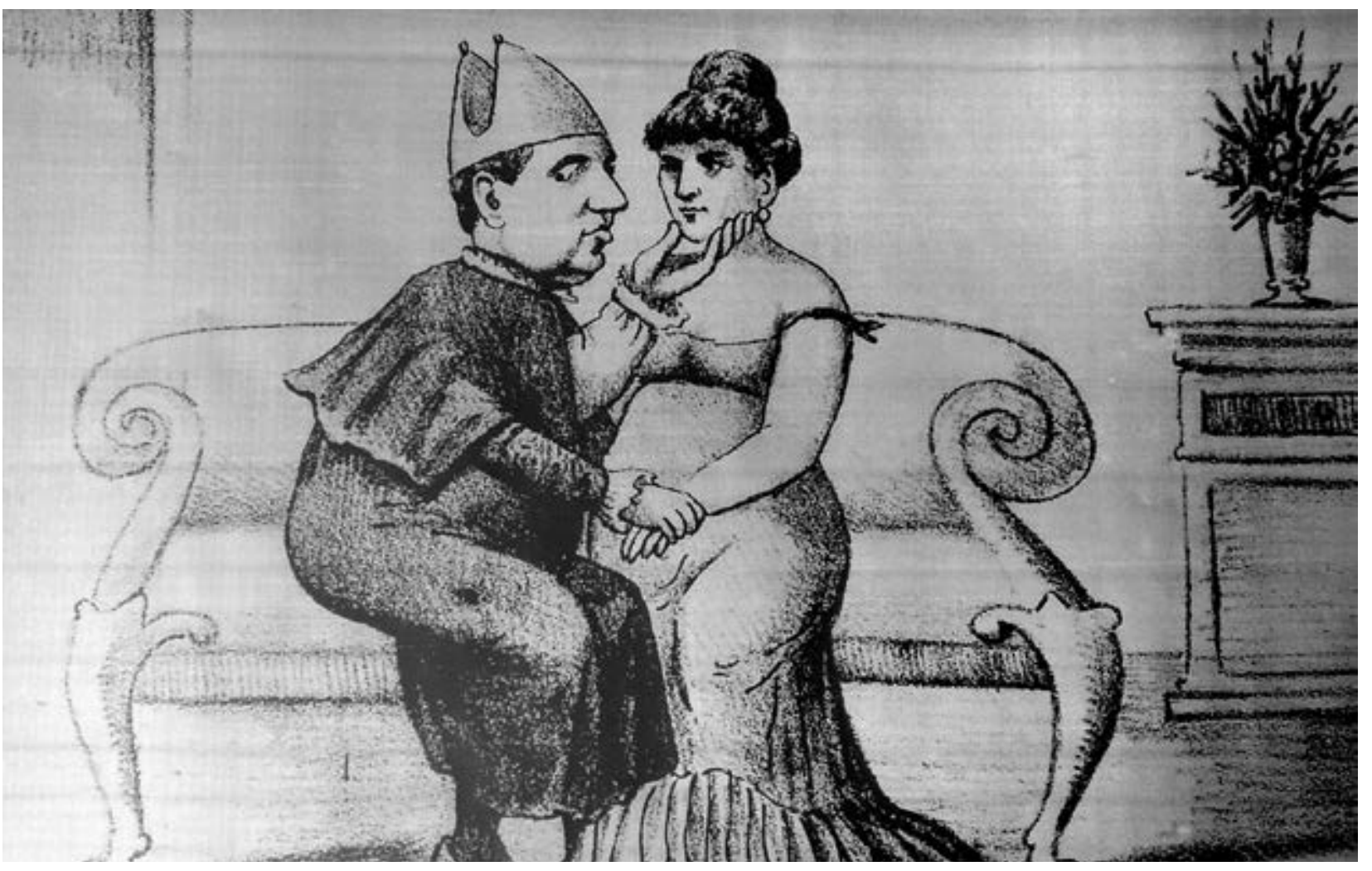

Tal como señala Pérez Vila (1979), las caricaturas políticas pueden ser difíciles de interpretar si se las saca de su contexto histórico. Debemos decir entonces que el enorme avance en materia de leyes laicas conquistado por el presidente Domingo Santa María, entre 1881 y 1886, experimentó una severa regresión con José Manuel Balmaceda, quien renovó sus relaciones con la Santa Sede. Es eso lo que denuncia Juan Rafael Allende al retratar al mandatario como un bebé.

Según el Diccionario de habla chilena (Academia Chilena, 1978), el término pollera no tiene solo el sentido de falda en el vestuario femenino, sino también la idea de "someterse mucho a la voluntad de la madre". De allí deriva el adjetivo pollerudo, aplicable a la subyugación de Balmaceda frente a la Iglesia, como un niño ante su madre, en situación de inferioridad e indefensión. Se recalca, así, su debilidad frente al poder de la Iglesia Católica y sus representantes que, tal como dice la glosa, "hacen extremos con él”.

En la caricatura, además, se retrata a un representante de la iglesia mostrándole al mandatario un juguete que encarna a un seminarista, mientras una beata despliega tras él un programa de gobierno. Esto último seguramente se debe, por un lado, al temor de la Iglesia de que se volviese a discutir en el Parlamento sobre la reforma de las leyes laicas y, por otro, a la permanente intromisión de la Iglesia en asuntos de Estado.

La sátira anticlerical, que abundó en los periódicos de Allende, se abocó a vicios como la gula, la lascivia y la avidez de riquezas como una forma de denunciar la incongruencia e irregularidades morales de los representantes del catolicismo. La crítica a la lujuria dentro de la Iglesia se ve reflejada en La confesión, caricatura publicada en El Padre Padilla el 2 de julio de 1885.

Con gran sentido del humor, Allende le lanza una mirada bufonesca al clero, en particular, al vicio de la concupiscencia, y denuncia la invitación a las fieles (o a las beatas) a actos lujuriosos durante la confesión. El voto de castidad es anulado burlescamente por Allende y los religiosos aparecen muy lejos de ejemplificar los principios cristianos que luego promulgan. El periodista se propone construir, sobre la cara visible de la Iglesia y sus representantes, un nuevo rostro: un rostro desviado moralmente, hipócrita y libertino; un mundo al revés. Vale decir, un mundo religioso donde prima el principio corporal por sobre el espiritual como una forma de degradar y vulgarizar la esfera católica.
Imagen 2: La confesión (caricatura). Fuente: Allende (1885) 
Como podemos observar, la prensa satírica, ya sea de corte político o anticlerical, es un instrumento más dentro de la armería de las luchas ideológicas y destaca por su enorme carga social. Ossandón (1998) la llama la prensa "parapeto" que, aun no representando por sí misma un poder, "sirve principalmente para estorbar el paso del adversario o para defender posiciones” (p. 26). La prensa satírica va a favorecer enormemente, junto a todas las otras voces de la prensa decimonónica, un espacio de intercambio y de discusión de ideas, va a representar una crítica constante y se va a situar, con plena potestad, en el proceso de intercambio ideológico donde las posturas de la comunidad se van formando y conquistando de forma constante.

\section{Reflexiones finales}

$\mathrm{Al}$ fin de este periplo, comprendemos la historia de estas prensas como un continuo asedio a las posiciones conservadores de la sociedad chilena. Utilizando el emergente espacio de la opinión pública, estos autores proyectaron los combates por sus públicos, privilegiando estrategias relevantes para la persuasión de los potenciales lectores. Es así como, desde la poesía hasta la caricatura, estos intelectuales tensaron la estabilidad del orden sociopolítico a tal punto que prologaron las guerras civiles del siglo XIX.

Si bien hoy vivimos en un mundo en que se nos bombardea cada vez con más y más imágenes, y con más quiebres entre la ficción/realidad, la prensa continúa en su posición de constructora de realidades e interviene en nuestra percepción, mediada por diversas estrategias publicitarias. ${ }^{15}$ De esta forma, lo social, lo cultural, así como lo económico, son aspectos que forman parte de nuestros soportes pues no existiria un 'afuera del texto', más bien todo sería parte del mismo texto.

Así lo vimos con el caso del periódico El Amigo del Pueblo (1850) que, oponiendo textos a las balas, defendió su posición burguesa en busca de la representatividad del pueblo. Lo hizo a través de un instrumento que, si bien se mostraba como patrimonio de la elite intelectual, también pudo ser usado en contra de la oligarquía conservadora. Ampliando lo social y culturalmente permitido, los redactores del periódico -los anónimos/conocidos miembros de la Sociedad de la Igualdad- encendieron su época desde la trinchera letrada para luego batirse por sus ideas en contra el gobierno de Manuel Montt en las Jornadas del 20 de abril de 1851 (como sugiere la expresión latina si vis pacem, para bellum).

Por otro lado, las flechas encendidas de Juan Rafael Allende fueron disparadas en un período de gran auge para la prensa nacional. La imagen y sus múltiples significados, junto con el envenenamiento correspondiente de la sátira, operaron como una transgresión de los límites establecidos en la época. Y aún más, los periódicos de Allende constituirian un franco intento de promover una campaña laicista en aquellos sectores medios y bajos que parecían quedar marginados de las discusiones públicas.

Allende ha sido, cabe decirlo, un autor poco transitado dentro de los estudios académicos. De esta manera, contamos con un vasto campo a explorar en relación a su capacidad de enfrentarse al poder y de intervenir en las contiendas sociales desde el soporte prensa. Pensando en futuras investigaciones sobre prensa decimonónica, creemos que la prensa de barricada y la prensa satírica se constituyen como una interesante puerta de entrada al estudio de un periodo fundacional, donde se buscaba construir identidad y donde se configuraron los rasgos fundamentales del futuro político, social y económico de los países americanos, cuyas tensiones se prolongan hasta el día de hoy.

\section{Referencias}

Allende, J.R. (2 de julio de 1885). La confesión. [Artículo de periódico]. Archivo de El Padre Padilla (MIC 1028-1037). Biblioteca Nacional de Santiago, Chile.

Allende, J.R. (2 de agosto de 1887). Entre polleras. [Artículo de periódico]. Archivo de El Padre Padilla (MIC 1028-1037). Biblioteca Nacional de Santiago, Chile. 
Allende, J.R. (5 de julio de 1888). El miedo lo hace obrar. [Artículo de periódico]. Archivo de El Padre Padilla (MIC 1028-1037). Biblioteca Nacional de Santiago, Chile.

Academia Chilena. (1978). Diccionario del habla chilena. Santiago, Chile: Universitaria.

Alonso, P. (2004). Construcciones impresas. Panfletos, diarios y revistas en la formación de los estados nacionales en América Latina, 1820-1920. Buenos Aires, Argentina: Fondo de Cultura Económica.

Anderson, B. (1993). Comunidades Imaginadas. Reflexiones sobre el origen y la difusión del nacionalismo. México D. F., México: Fondo de Cultura Económica.

A un fariseo (6 de mayo de 1850a). El Amigo del Pueblo. Recuperado de http://www.memoriachilena.cl/archivos2/pdfs/MC0056158.pdf

A un fariseo (7 de mayo de 1850b). El Amigo del Pueblo. Recuperado de http://www.memoriachilena.cl/archivos2/pdfs/MC0056158.pdf

Bajtín, M. (1987). La cultura popular en la Edad Media y el Renacimiento. Madrid, España: Alianza.

Blest Gana, A. (1861). Literatura chilena. Algunas consideraciones sobre ella. Discurso de don Alberto Blest Gana en su incorporación de la Facultad de Filosofía y Humanidades, el 3 de enero de 1861. Anales de la Universidad de Chile. Recuperado de http:// www.anales.uchile.cl/index.php/ANUC/article/view/3177/3089

Blest Gana, J. (1848). Consideraciones generales sobre la poesía chilena. Revista de Santiago, Santiago, 21, 337-353. Recuperado de http://www.memoriachilena.cl/602/w3-article-84735.html

Brunner, J. J., y Catalán, G. (1985). Cinco estudios sobre cultura y sociedad. Santiago, Chile: FLACSO.

Casullo, N. (1999). "La modernidad como autorreflexión" en Itinerarios de la modernidad: corrientes del pensamiento y tradiciones intelectuales desde la ilustración hasta la posmodernidad. Buenos Aires, Argentina: Eudeba.

Collier, S. (2005). Chile, la construcción de una república, 1830-1865: política e ideas. Santiago, Chile: Ediciones Universidad Católica de Chile.

Correa da Costa, J. (8 de mayo de 1850). Correspondencia. El Amigo del Pueblo, p. 3. Recuperado de http://www.memoriachilena.cl/ archivos2/pdfs/MC0056158.pdf

Correspondencia. (8 de abril de 1850). El Amigo del Pueblo, p. 3. Recuperado de http://www.memoriachilena.cl/archivos2/pdfs/ MC0056158.pdf
Donoso, R. (1950). La Sátira política en Chile. Santiago; Chile: Imprenta Universitaria.

El Amigo del Pueblo. (1 de abril de 1850). Colección Biblioteca Nacional de Chile. Recuperado de http://www.memoriachilena.cl/602/ w3-article-86258.html

El Petorquino. (27 de abril de 1850). El Amigo del pueblo, p. 3. Recuperado de http://www.memoriachilena.cl/archivos2/pdfs/ MC0056158.pdf

El sueño del verdugo. (4 de abril de 1850). El Amigo del Pueblo, p. 4. Recuperado de http://www.memoriachilena.cl/archivos2/pdfs/ MC0056158.pdf

Eusebio Lillo Robles (1826-1910). (s. f.). Memoria chilena. Recuperado de http://www.memoriachilena.cl/602/w3-article-100631.html

Francisco Bilbao Barquín (1823-1865). (s. f.). Memoria chilena. Recuperado de http://www.memoriachilena.cl/602/w3-article-631.html

Lillo, E. (1 de abril de 1850). La musa en día de Pascua. El Amigo del Pueblo, p. 3. Recuperado de http://www.memoriachilena.cl/ archivos2/pdfs/MC0056158.pdf

Ossandón, C. (1998). El crepúsculo de los sabios y la irrupción de los publicistas: prensa y espacio público en Chile (siglo XIX). Santiago, Chile: LOM Ediciones.

Palti, E. (2003). Los diarios y el sistema político mexicano en tiempos de la República Restaurada (1867-1876). En P. Alonso (Comp.), Construcciones impresas. Panfletos, diarios y revistas en la formación de los estados nacionales en América Latina, 1820-1920 (pp.167181). Buenos Aires, Argentina: Fondo de Cultura Económica.

Pérez Vila, M. (1979). La caricatura política en el siglo XIX. Caracas, Venezuela: Cuadernos Lagoven.

Ramos, J. (2003). Desencuentros de la modernidad en América Latina. Santiago, Chile: Cuarto Propio.

Santa Cruz, E. (2010). La prensa chilena en el siglo XIX. Santiago, Chile: Editorial Universitaria.

Santiago Arcos Arlegui (1822-1874). (s. f.). Memoria chilena. Recuperado de http://www.memoriachilena.cl/602/w3-article-31657.html

Sociedad de la Igualdad. (s. f.). Memoria chilena. Recuperado de http:// www.memoriachilena.cl/602/w3-article-94755.html

Subercaseaux, B. (2010). Historia del libro en Chile. Desde la colonia al Bicentenario. Santiago, Chile: LOM Ediciones.

Villalobos, L. (2015). La vigencia de Juan Rafael Allende. En G. Marín y A. Gouet, Memorias de un perro escritas por su propia pata. Santiago, Chile: Letra Capital Ediciones. 